importance of nuclear weapons in the functioning of the Yalta-Potsdam system of international relations that developed after the end of World War II, especially during the Caribbean crisis of 1962 as the most acute phase of the crisis in relations between the two superpowers. The article focuses on new approaches to the role of nuclear weapons in world politics after the collapse of the USSR, analyzes the modern strategy of Russia's nuclear deterrence that is set out in the Fundamentals of the State Policy of the Russian Federation in the Field of Nuclear Deterrence of June 2, 2020.

Keywords: nuclear weapons, nuclear power, world politics, system of international relations, Treaty on the Non-Proliferation of Nuclear Weapons (NPT), nuclear deterrence

ЮСУПОВА Гурия Ислангараевна - доктор философских наук, главный научный сотрудник Регионального центра этнополитических исследований Дагестанского федерального исследовательского центра РАН (367025, Россия, Республика Дагестан, г. Махачкала, ул. М. Гаджиева, 45;

Huria@list.ru)

МАГОМЕДАЛИЕВА Карина Магомедовна - старший преподаватель кафедры онтологии и теории познания факультета психологии и философии Дагестанского государственного университета (367026, Россия, Ресрублика Дагестан, г. Махачкала, ул. Шамиля, 16; karina557@таil.ru)

\title{
РЕЛИГИОЗНЫЙ ТЕРРОРИЗМ: НОВЫЕ ГЛОБАЛЬНЫЕ И РЕГИОНАЛЬНЫЕ ВЫЗОВЫ
}

\begin{abstract}
Аннотация. В статье исследованы особенности религиозного терроризма на глобальном, государственном, национальном и региональном уровне. В качестве методов научного анализа проблемы использованы системный метод, сравнительный анализ, диалектический подход. Автор проводит сравнительный анализ причин распространения религиозного терроризма в мире, Российской Федерации и в Северо-Кавказском регионе. В результате применения системного подхода предложено авторское определение категории «религиозный терроризм».
\end{abstract}

Ключевые слова: религиозный терроризм, реисламизация, национальная безопасность, Северный Кавказ, регион, экстремизм, радикализация ислама

$\mathrm{C}$ реди ключевых компонентов, формирующих глобальные угрозы и вызовы человечеству, одной из основных является распространение религиозного экстремизма и терроризма [Попова 2021: 41]. Религиозный терроризм в XXI в. превратился в глобальную угрозу первостепенной важности. Исследователи считают, что истоки современного терроризма следует искать в 60-х гг. прошлого века, и связывают его возникновение с распадом ведущих мировых колониальных империй. Однако в результате глобальных геополитических трансформаций последних десятилетий в терроризме произошли серьезные изменения политического, социального, военного характера [Загладин, Путилин 2006: 5]. Только изменив соответствующие условия функционирования социума, можно искоренить опасности экстремизма и терроризма [Дагестан: поиск... 2018: 11]. Метод системного анализа позволяет выделить среди причин распространения террористических практик в современном мире наиболее фундаментальные, или ключевые причины [Зеленцов 2021: 46]. Религиозное возрождение, религиозный фундаментализм, терроризм и экстремизм рассматриваются в качестве факторов, содействующих интенсификации религиозной идентичности [Магомедова 2019: 140]. Современный религиозный терроризм, развивающийся под идеологическим прикрытием исламистских лозунгов, имеет глубокие социальные, политические, социо- 
культурные корни. К ним относятся глобальное социальное неравенство, бедность, усиление социального разрыва между государствами, регионами. Следует особо выделить социальные корни распространения терроризма в молодежной среде. А.В. Сериков считает субъектным фактором распространения идеологии и практики религиозного экстремизма в молодежной среде наличие и углубление избыточного социального неравенства [Сериков 2020: 68]. Сохраняется, временами разрастаясь и приобретая характер военных конфликтов, противоречие между попытками насильственного распространения демократических ценностей западного образца, политической, социокультурной модернизации и протестной мобилизацией так называемых традиционных обществ, которая сопровождается ответным ростом этнической и религиозной идентификации. Можно считать еще одной социальной причиной распространения религиозного экстремизма и терроризма усиление социальной поляризации в странах с ярко выраженными процессами рекапитализации. Следствием этого является реанимация религиозных устремлений обнищавшего населения, нашедшего в религии идеи социальной справедливости и равенства. Поэтому противодействие религиозному терроризму в международном масштабе должно включать в себя не только организацию профилактических мер, создание четко функционирующей системы правового, силового подавления террористической деятельности, но и уничтожение социальной базы международного терроризма на уровне конкретных локальных сообществ. Локальные войны и конфликты, агрессивная вестернизация продолжают вызывать агрессивную ответную реакцию традиционных обществ, опирающихся на идеологическую необходимость защиты традиционных ценностей, весомым элементом которых является религия.

Некоторые исследователи рассматривают современный религиозный терроризм как проявление цивилизационного конфликта «Восток - Запад». На распространение терроризма в массовом масштабе на Ближнем Востоке повлияли действия западных спецслужб по созданию террористических группировок с целью укрепления и распространения своего геополитического лидерства в современном мире, военные действия США и поддержавших их западных стран в Ираке, Ливии, Сирии, ряде других стран, невиданный рост миграционных потоков. Продолжается политика западных стран по дезинтеграции и дестабилизации ситуации на постсоветском пространстве. Серьезную опасность представляет сегодня деятельность запрещенной в России экстремистской организации «Талибан», которая после вывода американских войск из Афганистана пришла к власти. Талибы могут превратиться из латентной в реальную угрозу не только для бывших республик Средней Азии, но и для южных регионов Российской Федерации, в частности Северного Кавказа.

Для России распространение идеологии и практики религиозного экстремизма и терроризма выпадает на период постсоветской истории, хотя его зачатки появились еще в 80-е гг. прошлого века. Широкое его распространение началось именно после распада СССР. Происшедшие в России радикальные трансформации, следствием которых стали рекапитализация, деидеологизация, политическая модернизация по западным образцам, не имели аналогов в мировой практике. В целях еще большей дестабилизации ситуации международный терроризм, поддержанный геополитическими соперниками Российской Федерации, организовал открытую кампанию, прежде всего на Северном Кавказе, ставшем в силу внутренних межэтнических противоречий, вооруженных конфликтов, военных действий на территории Чеченской Республики очагом нестабильности. 
В 2009 г. была утверждена Концепция противодействия терроризму в Российской Федерации. Она выделяет в качестве внешних угроз распространения террористической практики попытки международного организованного религиозного терроризма проникнуть и закрепиться в отдельных субъектах РФ для распространения идеологии и практики экстремизма и терроризма, создания сетевой террористической структуры. Также серьезную опасность представляют наличие очагов терроризма вблизи границ РФ, лагерей для подготовки террористов, финансовая поддержка рядом иностранных государств международных террористических организаций, усиление идеологического влияния экстремизма в информационном пространстве. О возрастании внешних и внутренних угроз экстремизма отмечается в Стратегии противодействия экстремизму в Российской Федерации до 2025 года. Также выделены внутренние факторы и причины распространения экстремизма и терроризма: межконфессиональные, внутриконфессиональные, межнациональные, другие социальные противоречия, недостаточно эффективная деятельность правоохранительных органов по противодействию терроризму, экстремизму, другим проявлениям организованной преступности, неэффективность противодействия идеологии экстремистской направленности в СМИ.

Деятельность транснациональных экстремистских и террористических организаций, поддержка иностранными государственными органами, спецслужбами деятельности экстремистских и террористических организаций на территории РФ с целью дестабилизации ситуации в стране и подрыва основ ее безопасности являются внешними угрозами.

Терроризм выполняет определенные функции в так называемой большой стратегии США. Он позволяет, скрывая настоящие мотивы внешней политики Вашингтона, маскируя их лозунгами демократии, быть эффективным средством достижения геополитических целей [Блохин, Синицын 2018: 28]. K угрозам внутреннего характера в Стратегии отнесена преступная деятельность радикально настроенных общественных, религиозных, некоммерческих организаций, отдельных лиц.

Если в рамках системного анализа рассматривать угрозы и риски религиозного терроризма для России, то наиболее остро они проявились на Юге РФ. В частности, Северо-Кавказский регион как система в рамках мегасистемы стал очагом агрессивного распространения религиозного терроризма и радикальной экстремистской идеологии, начиная с конца 80-х - начала 90-х гг. прошлого столетия. Распространение религиозного терроризма в регионе шло параллельно с активной реисламиацией, которая стремительно развернулась после распада СССР, вытеснила со временем реэтнизацию, создавшую множество межэтнических противоречий и спровоцировавшую войну на территории Чеченской Республики. Согласно ставшим известными спустя много лет данным, в результате ковровых бомбардировок погибли около 200 тыс. мирных граждан Чечни, около 300 тыс. чел. были вынуждены покинуть республику. Мы можем выделить следующие особенности реисламизации региона: рост религиозного сознания населения и числа религиозных организаций и культовых зданий; начало политизации ислама и усиление влияния религиозных организаций и их лидеров на общественно-политическую жизнь в регионе, их попытки стать активным политическим актором и создать свою нишу в региональном политическом пространстве; активную радикализацию ислама, которая сопровождалась распространением идей религиозно-политического экстремизма и терроризма.

Религиозный терроризм в регионе имел, наряду с общими для России причинами, также свои особенные причины распространения. Активизацию дея- 
тельности организаций международного терроризма исследователи связывают с особенностями нового геополитического положения региона, острыми проблемами кавказской и каспийской геополитики, устремлениями современных геополитических игроков. Сегодня возникли новые угрозы в этой области: активизация политики Турции в Кавказском регионе, незавершенность геополитической трансформации на Южном Кавказе, угроза распространения беженцев в связи с изменившейся ситуацией в Афганистане после прихода к власти талибов.

Внутренние причины распространения терроризма и религиозного экстремизма в регионе имеют свою специфику. Процессы радикализации ислама совпали с процессами так называемого этнического возрождения, что породило множество противоречий. Это переплетение сложных процессов этнической и религиозной мобилизации способствовало превращению СевероКавказского региона в самый острый очаг нестабильности в стране, а также продолжает и в наше время оставаться одним из основных конфликтогенных факторов [Сущий 2021: 73]. Среди социальных причин распространения религиозного терроризма выделяются особенности этносоциальной стратификации субъектов региона, резкое отставание темпов социально-экономического развития региона по сравнению с общероссийскими показателями. Самыми низкими среди субъектов РФ продолжают оставаться уровень зарплаты, показатели уровня жизни. Наряду с этим для региона в целом характерен высокий уровень безработицы и вынужденная миграция за пределы региона. Следует учитывать также возрастные особенности населения республик Северного Кавказа, почти половину которого составляет молодежь, более склонная к радикализации и восприятию идеологии экстремизма и терроризма.

Мы можем выделить особенности идеологической причины распространения религиозного терроризма в регионе наряду с наличием общероссийских факторов: это деидеологизация и наполнение образовавшегося идеологического вакуума этническим сепаратизмом, национализмом, шовинизмом, религиозной нетерпимостью, радикальными экстремистскими и террористическими идеями. К таковым можно отнести идейные противоречия между сторонниками так называемого чистого ислама и приверженцами традиционного для Северного Кавказа ислама. Как отмечает И.П. Добаев, данному расколу в северокавказской мусульманской умме способствовали такие факторы, как открытие информационных центров при посольствах ряда мусульманских государств, приезд многочисленных представителей религиозных миссионерских организаций, неконтролируемый выезд молодых людей для получения исламского образования [Добаев 2020: 203]. Несмотря на то что в последние годы уровень преступности террористической направленности снижается, религиозный терроризм сохраняет свою опасность на государственном и региональном уровне, сохраняются благоприятные условия для вовлечения в ряды его сторонников новых адептов и исполнителей из молодежной среды.

По данным Генеральной прокуратуры РФ, в 2020 г. в стране совершено 397 преступлений террористической направленности, в т.ч. 71 преступление было предотвращено на подготовительной стадии. По сравнению с 2019 г. в 2020 г. число выявленных преступлений экстремистского характера увеличилось на 42\%. Было совершено 833 таких преступления, из них 367 связаны с публичными призывами к экстремистской деятельности (в т.ч. 339 совершены с использованием Интернета) ${ }^{1}$.

\footnotetext{
1 Российская газета. 2021. 3 февр.
} 
Среди субъектов СКФО больше всего преступлений террористической направленности было зарегистрировано в Республике Дагестан, Чеченской Республике и Кабардино-Балкарской Республике, причем в этих республиках их было в 2019 г. совершено примерно столько же, сколько во всех других регионах СКФО. По данным МВД РД, в 2020 г. в Республике Дагестан выявлено 700 преступлений террористического характера. На территории РД было убито 9 боевиков, обнаружена и пресечена деятельность нескольких «спящих» ячеек. Как отметил глава МВД РД Абдурашид Магомедов, в деятельности незаконных вооруженных бандформирований за рубежом принимали участие 150 чел., среди которых много женщин ${ }^{1}$.

На основании сказанного выше можно сделать следующие выводы.

Изучив феномен современного религиозного терроризма на основе системного подхода (системный анализ позволил нам рассмотреть его в границах мегасистемы - системы - подсистемы, системный синтез позволил выявить основные компоненты, общие характеристики), мы предлагаем следующее авторское определение религиозного терроризма. Религиозный терроризм разновидность террористической практики, сторонники которой используют религиозную идеологию для мобилизации своих сторонников на насильственные противоправные действия.

Религиозный терроризм, радикализм и экстремизм продолжают оставаться серьезной реальной и потенциальной угрозой на глобальном, государственном, национальном и региональном уровне.

В условиях, когда сложилась новая антагонистическая формация, для которой характерно новое классовое расслоение, обусловленное отношениями эксплуатации [Давыдов 2021: 3], существует социальная база для дальнейшего вовлечени молодежи в террористическую деятельность.

Усиление реисламизации, сопровождавшейся определенным идеологическим вакуумом в связи с кризисом предшествовавшей идеологии, вызвав рост идеологических противоречий в рамках различных течений ислама, создало идейные предпосылки для распространения идеологии религиозного терроризма и экстремизма на Северном Кавказе.

Новые угрозы глобального характера, национальные и региональные риски требуют совершенствования стратегии противодействия религиозному терроризму и экстремизму, преодоления имеющихся недостатков программноцелевого подхода в организации этой работы, придания ей более эффективного характера, адекватного современной ситуации.

Повышение эффективности противодействия религиозному терроризму и экстремизму возможно только на основе долгосрочной работы по созданию идеологии нового типа, учитывающей положительный опыт советского периода истории и новые потребности.

\section{Список литературы}

Блохин К.В., Синицын И.М. 2018. «Стратегический терроризм» США как угроза национальной безопасности России: генезис и особенности. - Власть. Т. 26. № 5. С. 28-34.

Давыдов Д.А. 2021. Посткапитализм и классовая трансформация в современном обществе: от класса-освободителя к новому антагонизму? - Социс. Социологические исследования. № 6. С. 3-13.

Дагестан: поиск эффективных мер борьбы с экстремизмом и терроризмом. 2018. Махачкала: ИД «Дагестан». 240 с.

\footnotetext{
1 Riadagestan.ru (проверено 29.09.2021).
} 
Добаев И.П. 2020. К вопросу о религиозной чистоте «истинного ислама». Гуманитарий Юга России. № 3. С. 202-215.

Загладин Н.В., Путилин Б.Г. 2006. Международный терроризм: истоки, проблемы, противодействия. М.: Русское слово. 152 с.

Зеленцов М.Ю. 2021. Комплекс факторов, способствующих современному религиозному терроризму. - Вопросы безопасности. № 1. С. 46-70.

Магомедова М.3. 2019. Религиозность северокавказского социума в условиях глобализации. Этнополитические и конфессиональные аспекты обеспечения региональной безопасности. Махачкала: Изд-во РЦЭИ ДНЦ РАН. 272 с.

Попова Л.А. 2021. Глобальная угроза терроризма: современное состояние и меры противодействия. - Вопросы безопасности. № 2. С. 41-53.

Сериков А.В. 2020. Радикализм и экстремизм в российской молодежной среде в контексте избыточных социальных неравенств. - Гуманитарий Юга России. Т. 9. № 6. С. 68-79.

Сущий С.Я. 2021. Конфликтогенный потенциал Северного Кавказа на рубеже 2020-х годов: факторы и основные тренды. - Научная мысль Кавказа. № 1. C. $72-78$.

YUSUPOVA Guriya Islangaraevna, Dr.Sci. (Philos.), Chief Researcher of the Regional Center for Ethnopolitical Studies, Dagestan Federal Research Center, Russian Academy of Sciences (45 M. Gadzhieva St, Makhachkala, Republic of Dagestan, Russia, 367025; Huria@ List.ru)

MAGOMEDAlIEVA Karina Magomedovna, Senior Lecturer at the Chair of Ontology and Theory of Knowledge, Dagestan State University (16 Shamilya St, Makhachkala, Republic of Dagestan, Russia, 367026; karina557@mail.ru)

\section{RELIGIOUS TERRORISM: NEW GLOBAL AND REGIONAL CHALLENGES}

\footnotetext{
Abstract. The article examines the features of religious terrorism at the global, state, national and regional level. The authors use system method, comparative analysis, and dialectical approach as methods of scientific analysis of the problem. The article carries out a comparative analysis of the reasons for the spread of religious terrorism in the world, the Russian Federation and in the North Caucasus Region. As a result of the application of the system approach, the authors propose the definition of the category of religious terrorism.

Keywords: religious terrorism, re-Islamization, national security, North Caucasus, region, extremism, radicalization of Islam
} 